\title{
HIV/AIDS awareness among Female Sex Workers
}

\author{
Dr. Archana Shukla ${ }^{1}$, Deepti Mehrotra ${ }^{2}$
}

\section{ABSTRACT}

Context / background: The present study endeavourers to cast a glance at HIV/AIDS awareness among Female Sex Workers in CREATE (Centre for Rural Entrepreneurship and Technical Education) at Lucknow.

Aim: To explore HIV/AIDS awareness among female sex workers.

Methods: An ex post facto research with an exploratory orientation was conducted, on 50 female sex workers selected on the basis of purposive sampling (age ranged 20-30 years). An effort was made to identify the level of awareness among female sex workers through self devised questions. Percentage analysis was done.

Results: Results revealed that majority of female sex workers were aware of HIV/AIDS, STD, there causes and preventive aspects.

Conclusions: Though the picture seemed somewhat positive yet it is pathetic that almost half of the sample seemed either confused or unaware of the essential concepts regarding HIV/AIDS.

Keywords: Female sex worker, HIV/AIDS, STD, prostitution.

Human immunodeficiency virus infection / acquired immunodeficiency syndrome (HIV/AIDS) is a disease of the humanimmune system caused by infection with human immunodeficiency virus (HIV) Sepkowitz (2001).

India has the third largest number of people living with HIV/AIDS. As per the 2008-09 HIV/AIDS estimates, there are an estimated 23.9 lakh people currently living with HIV/AIDS in India with an adult prevalence of 0.31 percent in 2009 www.nacoonline.org (2012)

Based on HIV/AIDS Sentinel Surveillance 2008-09, it is estimated that 23.9 lakh people are infected with HIV/AIDS in India, of whom 39\% are female and $4.4 \%$ are children. Though the estimates highlight an overall reduction in adult HIV/AIDS prevalence and HIV/AIDS incidence (new infections) in India.

\footnotetext{
${ }^{1}$ Assistant Professor, Department of Psychology, University of Lucknow, Lucknow.

${ }^{2}$ Masters of Psychology, Department of Psychology, University of Lucknow, Lucknow. 
Adult HIV/AIDS prevalence at national level has declined from $0.41 \%$ in 2000 to $0.31 \%$ in 2009. The estimated number of new annual HIV/AIDS infections has declined by $56 \%$ over the past decade from 2.7 lakh new infections in 2000 to 1.2 lakh in 2009.

HIV/AIDS epidemic in India is concentrated in nature. The HIV/AIDS prevalence among the High Risk Groups..

\section{High Risk Groups (HRG)}

1. Female Sex Workers (FSW)

2. Men who have Sex with Men (MSM)

3. Transgender (TG)

4. Injecting Drug Users (IDU)

\section{Bridge Populations}

1. Truckers

2. Migrants

FSW populations in most countries are highly vulnerable to HIV/AIDS infection, female sex workers have been linked with the HIV/AIDS epidemic since its onset, due to the nature of their work. In India, sexual transmission is responsible for 87.4 percent of reported HIV cases and HIV prevalence is high among sex workers (both male and female) and their clients. A large proportion of women with HIV appears to have acquired the virus from their regular partner who was infected during paid sex. Overall HIV prevention efforts targeted at sex workers are increasing in India. HIV information and awareness among sex workers appears to be low, especially among those working in the streets. This intrigued the researcher to take up this topic for the research.

"Prostitution is the business or practice of engaging in sexual relations in exchange for payment”- Merriam - Webster Dictionary (2013).

Prostitution is sometimes described as commercial sex. Each country has its own legal status on prostitution from being permissible but unregulated, to an enforced or unenforced crime or to a regulated profession. The Fondation Scelles (2012) has released its latest report on Sexual Exploitation which states that at this given moment there are 40-42 million prostitutes at work, which is more than the population of Australia and Canada. A cursory glance at the Indian scenario.

\section{- Indian Scenario}

Presently there are an estimated 3 million women working as prostitutes in India. 1.2 million of the sex workers are under the age of 18. The average age that a girl enters the sex trade in India is reported to be between 9 and 12 years old. The human trafficking industry in India is estimated to generate \$4 Billion a year MacAskill and Pradhan 2013. 
Sex work in India is neither legal nor illegal it is tolerated since prostitutes can practice their trade privately but cannot legally solicit customers in public. They come across problems in all walks of life as they are being abused physically and mentally. Sex workers are unable to get help from police in situations where they are victims of violence.

Sex workers in India are discriminated against within public services and subjected to violence from clients, brokers, brothel owners, family members and police. The situation is exacerbated by laws that criminalize sex work that push them on the streets, into unsafe and vulnerable situations for example transmission of HIV/AIDS.

The life of the female sex workers seemed to be seriously threatened in many aspects. There is a high need for the Health Professionals to be sensitive to develop empathy and to provide a platform for the female sex workers to make them empowered and assertive. With all the reasons, necessity of exploring the HIV/AIDS awareness among the female sex worker was felt.

A string of questions emerged in the mind while going through the problems of FSW viz. How much aware they are of HIV/AIDS and to what extent this awareness plays a role into their dayto-day working as FSW? Do they know how HIV/AIDS spreads and what are the preventive measures? Do they use precautions? Do they use precautions with their regular partner?

This intrigued the researcher to take up the present research. The present study is an attempt to give a directional view of the situation of female sex workers and providing an answer to some of the selective and significant questions.

\section{METHOD}

\section{Purpose}

Explore the awareness of HIV/AIDS among female sex workers.

\section{Design}

The present study is an ex post facto research with exploratory orientation.

\section{Sample}

The participants for the present study comprised of 50 female sex workers selected on the basis of purposive sampling from N.G.O CREATE (Centre for Rural Entrepreneurship and Technical Education) at Lucknow. They were within the age group of 20-30 years; beside most of them were married and semi literate.

\section{Measurement Tool}

A self devised questionnaire was used that comprised of 10 items.

\section{Procedure}

For developing an interview schedule first all the information from local, national and international sources were scanned. Before starting the main administration permission was seeked from the head of the organization besides only those participants were included in the 
study which were willing and which gave their consent for the present study. A pilot study was done to get ease with the procedure of data collection as well as to get a prior glimpse of the problems to be faced during the actual data collection. For this purpose, a study was done on a sample of 10 female sex workers. Slight modifications were done in terms of language of the questions.

\section{Data Analysis}

For the better understandings of the questions, all the questions were asked in Hindi that is the local language of the respondents:

1. What is HIV/AIDS?

2. What is the difference between HIV and AIDS?

3. How HIV/AIDS spreads?

4. When is world AIDS day?

5. How to identify HIV/AIDS?

6. What is the HIV/AIDS virus life expectancy in human body?

7. How HIV/AIDS transmits to others after being infected?

8. What is the duration of HIV/AIDS testing?

9. Do you know about free testing of HIV/AIDS?

10. How to prevent HIV/AIDS?

\section{RESULTS AND INTERPRETATION}

The schedule was designed to study the level of HIV/AIDS awareness among the Female Sex Workers. The schedule contained 10 questions. The following table gives a detail description of the responses given for each question given in the schedule:

\section{Meaning of HIV/AIDS}

Table: 1 Meaning of HIV/AIDS

\begin{tabular}{|c|c|}
\hline Yes & No \\
\hline $56.66 \%$ & $43.33 \%$ \\
\hline
\end{tabular}

The above table: 1 shows the meaning of HIV/AIDS. The responses show that $56.66 \%$ of the respondents knew what is HIV/AIDS By answering HIV/AIDS is a virus whereas $43.33 \%$ of the responses were the sex workers who were either confused between the responses or did not had any idea about what HIV/AIDS means. 


\section{Difference between HIV and AIDS}

Table: 2 Difference between HIV and AIDS

\begin{tabular}{|l|l|}
\hline Yes & No \\
\hline $60 \%$ & $40 \%$ \\
\hline
\end{tabular}

Table 2 reveals the knowledge of FSW about difference between HIV and AIDS. The responses show that $60 \%$ of the respondents knew that HIV and AIDS are different things I.e. HIV is a virus because of which AIDS spreads whereas $40 \%$ of the responses believed that HIV and AIDS are same.

\section{Means through which HIV/AIDS Spreads}

Table: 3 Means through which HIV/AIDS Spreads

\begin{tabular}{|c|c|}
\hline Yes & No \\
\hline $53.33 \%$ & $46.66 \%$ \\
\hline
\end{tabular}

The above table shows the awareness level of Female Sex Workers about how HIV/AIDS spreads? The responses show that $53.33 \%$ of the respondents knew what were the means through which HIV/AIDS spreads? I.e. HIV/AIDS spreads through unsafe sex, reuse of syringes, from mother to child and infected blood transplant whereas $46.66 \%$ of the responses gave partial responses i.e. combining the first two or only unsafe sex or having no knowledge about the spreading of HIV/AIDS.

Shrotri, Shankar, Sutar, Joshi, Suryawanshi, Pisal, Bharucha, Phadke, Bollinger and Sastry (2003) found that knowledge of primary transmission routes, such as sexual contact and use of unsterile needles was over 75\%. Nearly half of the women displayed knowledge of modes where HIV was not transmitted.

The awareness of transmission of HIV/AIDS among FSW is high as compared with others this is due to the reason that FSWs are dealing with sexual activities in their daily life.

\section{World AIDS day}

Table: 4 World AIDS day

\begin{tabular}{|c|l|}
\hline Yes & No \\
\hline $36.66 \%$ & $63.33 \%$ \\
\hline
\end{tabular}

The above table shows the awareness of World AIDS Day. The responses show that $36.66 \%$ of the respondents knew that World AIDS Day is celebrated on $1^{\text {st }}$ December whereas 63.33\% of the responses showed that they do not have any idea about when is the World AIDS Day celebrated. 


\section{Identify HIV/AIDS}

Table: 5 Identify HIV/AIDS

\begin{tabular}{|l|l|}
\hline Yes & No \\
\hline $56.66 \%$ & $43.33 \%$ \\
\hline
\end{tabular}

The above table shows identification of HIV/AIDS infection. The responses show that $56.66 \%$ of the respondents knew that identification of HIV/AIDS infection is done through blood testing whereas $43.33 \%$ of the responses showed that they either do not have any idea about identification of HIV/AIDS infection or have misinformation regarding HIV/AIDS testing.

\section{HIV/AIDS virus life expectancy in human body}

Table: 6 HIV/AIDS virus life expectancy in human body

\begin{tabular}{|l|l|}
\hline Yes & No \\
\hline $40 \%$ & $60 \%$ \\
\hline
\end{tabular}

The above table shows the awareness level of Female Sex Workers on knowledge about HIV/AIDS virus life expectancy in human body. The responses show that $40 \%$ of the respondents knew that HIV/AIDS virus can live for whole of its life in human body whereas $60 \%$ of the responses showed that they either do not have any idea about HIV/AIDS virus life expectancy in human body or have misinformation regarding HIV/AIDS virus life expectancy in human body.

\section{Transmitting HIV/AIDS to others after being infected}

Table: 7 Transmitting HIV/AIDS to others after being infected

\begin{tabular}{|l|l|}
\hline Yes & No \\
\hline $43.33 \%$ & $56.66 \%$ \\
\hline
\end{tabular}

The above table shows the knowledge about transmitting HIV/AIDS to others after being infected. The responses show that $43.33 \%$ of the respondents knew that people can transmit to others if they are infected whereas $56.66 \%$ of the responses showed that they either do not have any idea about or have misinformation regarding transmitting HIV/AIDS to others after being infected.

\section{Duration of HIV/AIDS testing}

Table:8 Duration of HIV/AIDS testing

\begin{tabular}{|c|c|}
\hline Yes & No \\
\hline $60 \%$ & $40 \%$ \\
\hline
\end{tabular}

The above table shows the awareness about duration of HIV/AIDS testing. The responses show that $60 \%$ of the respondents knew that HIV/AIDS testing is done at every six month interval 
whereas $40 \%$ of the responses showed that they either they do not have any idea about or have misinformation regarding at what duration HIV/AIDS testing is done.

\section{Free testing of HIV/AIDS}

Table: 9 free testing of HIV/AIDS

\begin{tabular}{|c|c|}
\hline Yes & No \\
\hline $63.33 \%$ & $36.66 \%$ \\
\hline
\end{tabular}

The above table shows the awareness level of Female Sex Workers about free testing services for HIV/AIDS. The responses show that $63.33 \%$ of the respondents knew that free testing services are primarily given at ICTC Centre while $36.66 \%$ of the responses showed that they either they do not have any idea about free testing services or have misinformation regarding the department providing free test services.

\section{Prevention of HIV/AIDS}

Table: 10 Prevention of HIV/AIDS

\begin{tabular}{|l|c|}
\hline Yes & No \\
\hline $70 \%$ & $30 \%$ \\
\hline
\end{tabular}

The above table shows the awareness level of Female Sex Workers on knowledge about prevention of HIV/AIDS. The responses show that $70 \%$ of the respondents knew that condoms help in prevention of HIV/AIDS whereas $30 \%$ of the responses either have no idea about condom usage in HIV/AIDS prevention or do not have right information regarding HIV/AIDS prevention.

Shrotri, Shankar, Sutar, Joshi, Suryawanshi, Pisal, Bharucha, Phadke, Bollinger and Sastry (2003) found that Fifty-three percent of women were able to mention at least one method of prevention.

\section{Conclusion}

To sum up the picture as pertaining to HIV/AIDS awareness what come forth was the majority of female sex workers were aware that HIV/AIDS is a virus. Further majority of sample knew that HIV and AIDS are different that is HIV is a virus because of which AIDS spreads.

Most of the respondents knew the factor through which HIV/AIDS spreads. With reference to identification of HIV/AIDS infection the more than half of responses show that identification of HIV/AIDS infection is done through blood testing. Data revealed that majority of female sex worker do not have any idea about HIV/AIDS virus life expectancy in human body.

Maximum number of the respondents are aware that HIV/AIDS testing is done at every six months interval, they knew that condoms helps in prevention of HIV/AIDS and they are aware of free testing services. 
Though the picture seemed somewhat positive yet it is pathetic that almost half of the population seemed either confused or unaware of the essential concepts regarding HIV/AIDS.

\section{IMPLICATIONS}

As mentioned earlier this study is a small attempt to bring to fore some basic realities of FSW. Yet a great deal remains to be explored as enormous amount of knowledge about prostitution was gained during the course of working in this area, but what becomes most clear during this effort is the vast amount that remains unknown, undocumented and unspoken.

The exact number of female sex workers in India is open to dispute, the exact number of sex workers is unknown and calculating the number of female sex workers is very difficult as sex work is mostly hidden and the population is transient, with people moving in and out of sex work constantly.

Despite tall talks of social welfare, women empowerment and community development female sex worker is the grass root reality. An effort must be done to bring them into main stream, to build a platform where one can uncover the crude realities existing in society. The need of the hour is to spread more awareness especially to FSW as they are dealing to sexual activities in their daily life and they are more prone to sexual transmission of HIV/AIDS. Hence strong step needs to be taken by social worker, community welfare and other health professionals.

The steps taken by the government in this area seems somewhat satisfactory but yet much remains to be still done.

\section{REFERENCES}

Sepkowitz KA (June 2001). "AIDS - the first 20 years". N. Engl. J. Med. 344 (23): 1764-

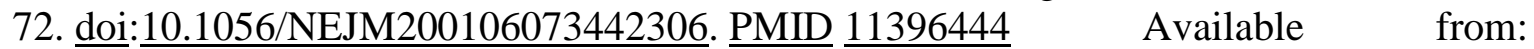
http://en.wikipedia.org/wiki/HIV/AIDS

Department of AIDS Control National AIDS Control Organisation Ministry of Health \& Family Welfare Government of India. Available from: www.nacoonline.org 2011-2012

Merriam Webster, "Prostitution - Definition and More from the Free Merriam-Webster Dictionary” Retrieved 19 September 2013. Available from: http://en.wikipedia.org/wiki/Prostitution

Charpenel. Y, Fondation Scelles , Sexual exploitation ,Economica ,2012 Available from: http://www.businessinsider.com/there-are-42-million-prostitutes-in-the-world-and-hereswhere-they-live-2012-1?IR=T

MacAskill. A and Pradhan. B, “Sold for Sex at Puberty Village Girls’ Fate in India,” Bloomberg Businessweek, September 18, 2013. Available from: http://www.havocscope.com/number-of-prostitutes-in-india/

Shrotri. A, Shankar. A V, Sutar.S, Joshi.A, Suryawanshi.N, Pisal. H, Bharucha. K E, Phadke. M A, Bollinger. R C and Sastry. J Awareness of HIV/AIDS and household environment of pregnant women in Pune, India, International Journal of STD \& AIDS 2003; 14: 835-839. Available from:http://www.hawaii.edu/hivandaids/Awareness_of_HIVAIDS_and_Household_Envir o_of_Preg_Women_India.pdf 